OPEN ACCESS

Edited by:

Daniel Moore,

University of Toronto, Canada

Reviewed by:

Katsuhiko Suzuki,

Waseda University, Japan

Michael D. Roberts,

Auburn University, United States

Glen Davison,

University of Kent, United Kingdom

${ }^{*}$ Correspondence:

Scott C. Forbes

ForbesS@brandonU.ca

Specialty section:

This article was submitted to Sport and Exercise Nutrition,

a section of the journal

Frontiers in Nutrition

Received: 28 November 2018

Accepted: 11 February 2019

Published: 01 March 2019

Citation:

Forbes SC and Bell GJ (2019) Whey Protein Isolate Supplementation While

Endurance Training Does Not Alter

Cycling Performance or Immune Responses at Rest or After Exercise.

Front. Nutr. 6:19.

doi: 10.3389/fnut.2019.00019

\section{Whey Protein Isolate Supplementation While Endurance Training Does Not Alter Cycling Performance or Immune Responses at Rest or After Exercise}

\author{
Scott C. Forbes ${ }^{1 *}$ and Gordon J. Bell ${ }^{2}$ \\ ${ }^{1}$ Department of Physical Education, Faculty of Education, Brandon University, Brandon, MB, Canada, ${ }^{2}$ Faculty of \\ Kinesiology, Sport and Recreation, University of Alberta, Edmonton, AB, Canada
}

This study examined whey protein isolate supplementation combined with endurance training on cycling performance, aerobic fitness and immune cell responses. Eighteen male cyclists were randomly assigned to either placebo (PLA) or whey protein supplementation (WS; $1.0 \mathrm{~g} \cdot \mathrm{kg}$ body mass $^{-1} \cdot \mathrm{d}^{-1}$ in addition to their dietary intake). Both groups completed the identical endurance training program, 4 days per week for 6 weeks. Blood samples were obtained at rest and after 5 and $60 \mathrm{~min}$ of recovery from a simulated $40 \mathrm{~km}$ cycling time trial $(T)$ and were repeated after training. Baseline dietary intake of protein prior to supplementation was $1.52 \pm 0.45$ and $1.46 \pm 0.44$ $\mathrm{g} \cdot \mathrm{kg}$ body mass ${ }^{-1} \cdot \mathrm{d}^{-1}$ for the WS and PLA groups, respectively. There were similar improvements in TT performance (WS: $71.47 \pm 12.17$ to $64.38 \pm 8.09 \mathrm{~min}$; PLA: 72.33 \pm 12.79 to $61.13 \pm 8.97 \mathrm{~min}$ ), and peak oxygen uptake (WS: $52.3 \pm 6.1$ to $56.1 \pm$ $5.4 \mathrm{~mL} \cdot \mathrm{kg}^{-1} \cdot \mathrm{min}^{-1}$; PLA: $50.0 \pm 7.1$ to $54.9 \pm 5.1 \mathrm{~mL} \cdot \mathrm{kg}^{-1} \cdot \mathrm{min}^{-1}$ ) after training in both groups. White blood cells (WBC) and neutrophil counts were elevated 5 min after the $\Pi$ and further increased after $60 \mathrm{~min}(P<0.05)$. The exercise-induced increase in WBC and neutrophil counts at 5 and 60 min after the $\Pi$ were attenuated after training compared to before training $(P<0.05)$. Lymphocytes increased 5 min after the $\Pi$ and decreased below rest after $60 \mathrm{~min}$ of recovery $(P<0.05)$. Following training lymphocytes were lower after $60 \mathrm{~min}$ of recovery compared to before training. There was no change in natural killer cell activity with exercise, training or between groups. It was concluded that whey protein isolate supplementation while endurance training did not differentially change cycling performance or the immune response at rest or after exercise. However, endurance training did alter performance, aerobic fitness and some post exercise immune cell counts.

Keywords: exercise, white blood cells, neutrophils, lymphocytes, natural killer cells 


\section{INTRODUCTION}

Protein is an integral part of any diet but it is especially important for athletes $(1,2)$. The American Dietetic Association, American College of Sports Medicine, and the Dietitians of Canada (3) suggest a protein intake of $1.2-1.4 \mathrm{~g} \cdot \mathrm{kg}^{-1} \cdot \mathrm{d}^{-1}$ is necessary for endurance athletes, which is greater than the current recommended dietary allowance of $0.8 \mathrm{~g} \cdot \mathrm{kg}^{-1} \cdot \mathrm{d}^{-1}$ (4). Kato et al. (5) utilized the indicator of amino acid oxidation method during sub-chronic feeding and exercise protocols to demonstrate that endurance athletes require 1.6 to 1.8 $\mathrm{g} \cdot \mathrm{kg}^{-1} \cdot \mathrm{d}^{-1}$ to support training adaptations. However, chronic protein recommendations for endurance athletes to optimize recovery, training adaptations, and performance remains to be elucidated.

Acute or short term ( $\leq 4$ days) studies examining protein supplementation during endurance exercise have shown enhanced performance (6-9), however, evidence of chronic protein supplementation on endurance training adaptations and performance are limited. For example, protein supplementation [provided during exercise ( $38 \pm 4 \mathrm{~g}$ of protein) and after exercise $\left(29 \pm 5 \mathrm{~g}\right.$ of protein) for a total protein intake of $184 \pm 44 \mathrm{~g} \cdot \mathrm{d}^{-1}$ or $2.6 \mathrm{~g} \cdot \mathrm{kg}^{-1} \cdot \mathrm{d}^{-1}$ compared to an iso-caloric carbohydrate group whom was provided no protein during or immediately after exercise and ingested $120 \pm 38 \mathrm{~g}$ of protein $\cdot \mathrm{d}^{-1}$ or $1.7 \mathrm{~g}$ of protein $\cdot \mathrm{kg}^{-1} \cdot \mathrm{d}^{-1}$ ] during a 10 -day intensified training period did not enhance $30 \mathrm{~km}$ cycling time trial performance (10). More recently, 10 weeks of protein supplementation (protein group: $132 \mathrm{~g}$ of protein $\cdot \mathrm{d}^{-1}$ or $2.1 \mathrm{~g} \cdot \mathrm{kg}^{-1} \cdot \mathrm{d}^{-1}$; placebo group: $84 \mathrm{~g}$ of protein $\cdot \mathrm{d}^{-1}$ or $1.2 \mathrm{~g} \cdot \mathrm{kg}^{-1} \cdot \mathrm{d}^{-1}$ ) did not alter $5 \mathrm{~km}$ time trial, lower limb mitochondrial capacity, or body composition changes in recreationally trained runners that participated in progressive run training (11). On the contrary, Ferguson-Stegall et al. (12) and Robinson et al. (13) found that protein supplementation following endurance training for 4 and 6 weeks, respectively, enhanced whole body oxygen uptake compared to post exercise iso-caloric carbohydrate supplementation. Feguson-Stegall et al. (12) provided $0.31 \mathrm{~g} \cdot \mathrm{kg}^{-1}$ of protein with a carbohydrate solution compared to a iso-caloric carbohydrate placebo, while Robinson et al. (13) provided $20 \mathrm{~g}$ of protein after each training session. However, it is notable that the later study was performed in older, untrained individuals, and the literature has shown that older individuals experience a reduced anabolic response to protein compared to younger individuals (14).

Protein and amino acids in the diet or as a supplement are believed to assist in achieving optimal nutrition to support exercise responses, recovery and training adaptations (15). Maughan et al. (16) reported that $85 \%$ of the athletes surveyed consumed supplements, of which protein supplements were used by $53 \%$ of the athletes and they stated that they did so to improve recovery and health, as well as to treat an illness and/or because they were unsure their diet was adequate. As a result, athletes may attempt to increase protein intake in their daily diets and/or use protein supplements during periods of training (16). One popular protein supplement is whey protein isolate, a type of milk protein produced as a byproduct of cheese production. It contains a variety of amino acids including all the essential amino acids as well as some immunoglobins, growth factors and many other proteins known to have immuno-enhancing properties $(17,18)$. Endurance exercise can suppress certain components of the immune system for a period of several hours after exercise depending on the type of exercise performed (17, 19-21). This has been termed the "open window hypothesis" as it suggests that during this period of immune suppression after exercise, individuals may be more susceptible to upper respiratory tract infections [URTI; $(20,22,23)]$. Since, it is known that immune cells require adequate levels of amino acids for their function (24), protein supplementation may benefit endurance training athlete's immune function $(17,23)$. For example, Witard et al. (23) demonstrated that consuming a high protein diet $\left(3 \mathrm{~g} \cdot \mathrm{kg}^{-1} \cdot \mathrm{d}^{-1}\right)$ compared to an iso-caloric carbohydrate diet containing 1.5 $\mathrm{g} \cdot \mathrm{kg}^{-1} \cdot \mathrm{d}^{-1}$ of protein helped to minimize exercise-induced changes in lymphocyte distribution and self-reported upper respiratory illnesses following a large increase in training load ( $~ 70 \%$ increase in training intensity, an increase in training duration, and $1-2$ session $(\mathrm{s}) \cdot \mathrm{d}^{-1}, 7$ training days $\cdot \mathrm{wk}^{-1}$ from 1 session $\cdot \mathrm{d}^{-1}, 4-5$ training days $\left.\cdot \mathrm{wk}^{-1}\right)$. These results suggest that a high protein diet $\left(3 \mathrm{~g} \cdot \mathrm{kg}^{-1}\right)$ may be of benefit compared to a diet containing $1.5 \mathrm{~g} \cdot \mathrm{kg}^{-1}$ of protein on immune function in endurance trained athletes.

The purpose of this study was to examine the effect of whey protein isolate supplementation in addition to the athlete's habitual dietary protein intake combined with endurance training on cycling performance, cardio-respiratory fitness (peak $\mathrm{VO}_{2}$ and ventilatory threshold), as well as resting and post exercise immune cell responses. It was hypothesized that 6 weeks of cycling endurance training with protein supplementation would improve $40 \mathrm{~km}$ time trial performance, peak oxygen consumption and ventilatory threshold. Furthermore, endurance training combined with whey protein may improve the response of certain aspects of the immune system.

\section{MATERIALS AND METHODS}

\section{Participants and Experimental Design}

Eighteen male participants with a mean age and height of $27 \pm$ 7 years and $177.5 \pm 8.5 \mathrm{~cm}$ volunteered for this study. All were cyclists ranging in experience from 2 to 20 years of training and competition at a local and provincial level and were currently in early off-season cycling training prior to the start of this study. Each participant signed a Physical Activity Readiness Questionnaire (PAR-Q) and consent form and this study was reviewed and approved by a University Research Ethics Board.

All participants attended an orientation session where all details of the study were explained including how to accurately complete a 24 -h dietary intake record. It was confirmed at this meeting that the participants had no known food allergies and were lactose tolerant. The participants were also required to examine the laboratory equipment to be used for testing and training at this meeting. After completion of the pre testing, the participants were matched on $40 \mathrm{~km}$ time trial (TT) performance and then randomly assigned to one of two groups: a whey protein (WS) supplement group and a placebo (PLA) group, in attempt to ensure similar cycling ability between participants in each group. 
Both groups completed the identical exercise testing and blood sampling protocols before and after 6 weeks of the same mid off-season training program. The participants were required to abstain from other forms of training or consuming any other type of supplement of any kind while participating in this study. All training information was recorded by all participants in training log books and on a poster board in the training room that was checked weekly by the training supervisors and investigators.

\section{Exercise Testing}

Aerobic fitness and performance was assessed with a graded exercise test (GXT) and a simulated $40 \mathrm{~km}$ cycling TT. The GXT was performed on a Monark $818 \mathrm{E}$ cycle ergometer (Vansbro, Sweden) that began with a pedal revolution of $80 \mathrm{rpm}$ and a resistance setting that elicited a power output (PO) of 100 watts (W). Subsequently, PO was increased by $40 \mathrm{~W}$ every $2 \mathrm{~min}$ by increasing the resistance setting but maintaining the pedal rpm until a systematic increase (breakpoint) in the ventilatory equivalent for $\mathrm{VCO}_{2}$ was observed on the graphical display of the metabolic measurement system software $(25,26)$. PO was then increased by $40 \mathrm{~W}$ every minute until volitional exhaustion was reached (27). Respiratory gas exchange was measured using a Rudolph valve and head gear apparatus (Hans Rudolph Inc., Shawnee Mission, USA) and a metabolic measurement system (Medgraphics CPX ${ }^{\mathrm{TM}}$, St. Paul, USA). The oxygen uptake associated with the breakpoints for the ventilatory equivalent of $\mathrm{VO}_{2}$ (VT1) and $\mathrm{VCO}_{2}$ (VT2) was determined from the graphical display of these relationships after agreement by two different investigators $(25,26)$. Peak oxygen consumption $\left(\mathrm{VO}_{2}\right.$ peak) was defined as the highest $\mathrm{VO}_{2}$ reached prior to exhaustion (27). Heart rate (HR) was measured every minute using a Polar ${ }^{\circledR}$ T31 HR monitor (Polar Electro, Finland).

On a different day after $24 \mathrm{~h}$ of no exercise, a stimulated $40 \mathrm{~km}$ time trial (TT) was performed using each participant's own racing bicycle attached to an electromagnetic, rear wheel driven stationary cycling device (Tacx ${ }^{\mathrm{TM}}$ Cycleforce, Wassenaar, Netherlands) based on our previously published protocol (28). Each participant was required to use a Continental ultra-sport stationary cycling tire on the rear of their bicycles that was inflated to $110 \mathrm{psi}(758 \mathrm{kPa})$. The setup of the bicycles and $\mathrm{Tacx}^{\mathrm{TM}}$ were conducted according to the manufacturer and performed by the same investigator before and after training. The same Continental tires and $\mathrm{Tacx}^{\mathrm{TM}}$ devices were used by the same participant before and after training and both the tires and $\mathrm{Tacx}^{\mathrm{TM}}$ devices were only used for the $40 \mathrm{~km}$ TT testing. The participants were asked to consume a pre-test meal and hydrate in a manner similar to how they would prepare for a competitive road race within a $2-3 \mathrm{~h}$ period prior to the TT test. The participants were provided with a $\sim 20$ min warmup consisting of submaximal cycling and light stretching. After a brief 2 to $3 \mathrm{~min}$ preparation period, each participant was asked to treat the $40 \mathrm{~km}$ TT as they would a competitive race and complete the test as fast as they possibly could using their own experience to guide their pacing strategy. The participants were able to view their distance covered, speed and pedal rpm during the test from the software on the device's computer display. A standard 5min cycling cool down was required immediately after the TT.
Time at $40 \mathrm{~km}$ was taken from the device and HR was recorded during the test every $10 \mathrm{~km}$ from a Polar ${ }^{\circledR}$ heart rate monitor. The participants were provided with water ad libitum throughout the TT. Note that all TT tests were performed in the morning between 09:30 and 11:00 and the time of day, pre-test meal and order of testing for each participant was maintained before and after the 6-week training program.

\section{Blood Collection and Analyses}

Blood samples $(8-10 \mathrm{ml})$ were obtained from an antecubital vein by venipuncture at rest and 5 and $60 \mathrm{~min}$ after the $40 \mathrm{~km}$ cycling TT. The blood sampling protocol included resting blood samples at 07:30 to 08:00 following an overnight fast after 22:00 (water was allowed). The participants were then required to consume their "pre-race" meal including a hydration strategy that they would normally choose before a race and then 2$3 \mathrm{~h}$ later, the $40 \mathrm{~km}$ TT was performed followed by a blood sample at $5 \mathrm{~min}$ and $60 \mathrm{~min}$ post exercise. The blood was collected into vacutainers containing EDTA (Becton-Dickinson, Mississauga, Canada) and transferred on ice to the laboratory for further analysis. Differential blood cell counts for lymphocytes, neutrophils and leukocytes (white blood cells) were made with a Coulter ${ }^{\circledR}$ STKS flow cytometer (Beckman Coulter Inc, Mississauga, Canada) by an accredited laboratory (DynaLIFE Medical Laboratories, Edmonton, Canada). A separate aliquot of the blood sample was analyzed separately for natural killer cell activity (NKCA) from isolated peripheral blood mononuclear cells using a chromium release assay as previously detailed by our laboratory (29). Lytic units were calculated and used to represent NKCA (29).

\section{Supplementation Protocol}

During pre-testing, each participant completed a 3 day dietary record ( 2 week days and 1 weekend day) of all food and fluid intake that was analyzed using a nutritional software program (Food Processor II, ESHA, Version 7.9, Salem, USA). The proportion and amount of protein, carbohydrate and fat as well as total caloric intake was determined and averaged across the 3 days. Any observed inconsistencies in the recordings were noted and immediately clarified with the participants. All participants were asked to maintain their regular diet during the recording period and throughout the study.

For the WS group, an additional $1.0 \mathrm{~g} \cdot \mathrm{kg}$ body $\mathrm{mass}^{-1} \cdot \mathrm{d}^{-1}$ of whey protein isolate powder containing 92\% protein (Land O' Lakes, St. Paul, USA) was calculated for each participant and added to their diet. To ensure the quality of the supplement, blood amino acid profiles were assessed on another group of subjects (30). The placebo group was provided with a carbohydrate polymer powder (Polycose ${ }^{\circledR}$, Abbot Laboratories Inc., Columbus, USA) in an amount that matched the additional calories associated with the increase in energy intake of the protein consumed in the WS group. This was done to reduce the chance that any observed changes might be due to a difference in caloric intake between groups. To do this, the amount of whey protein powder required for each WS participant was determined and the caloric equivalent was calculated (4 kcal per gram of protein). Then, the amount of carbohydrate 
polymer powder that equaled the caloric equivalent of the protein supplement was determined for each of the participants in the PLA group based on their individual body mass. The participants were provided with white plastic containers containing their respective powders to consume and a measuring scoop to accurately measure the supplement. The participants were asked to consume their respective supplement powders with their regular meals (breakfast, lunch, supper) in 3 amounts spread throughout the day for 6 days a week with 1 day off (Sunday) on both training and testing days. Recent research has shown positive net protein balance following resistance exercise when protein is distributed throughout the day (31). The participants were given a 1 week supply of their respective supplement at a time which allowed for closer monitoring of the supplement protocol. Body mass of all participants was measured after 3 weeks and any changes were used to adjust the amount of supplement consumed to maintain $1.0 \mathrm{~g} \cdot \mathrm{kg}^{-1} \mathrm{~d}^{-1}$ of protein supplement and caloric equivalence between groups.

\section{Training Program}

The training program was a meso-cycle of 6 weeks performed at the midpoint of the cycling off-season. The physical training program consisted of 4 days per week of stationary cycling (Monday, Tuesday, Thursday, Friday) and 1 day a week of maintenance strength training (Wednesday or Saturday) with 1 day off a week (Sunday). Mondays and Fridays were continuous cycling at a HR equivalent to the intensity that elicited VT1 determined during the GXT and began with $45 \mathrm{~min}$ and progressively increased to $60 \mathrm{~min}$ during the last week of the study. Tuesdays consisted of 2 long intervals of cycling at a HR at or just above the HR that elicited VT2. The duration of intervals increased from $17.5 \mathrm{~min}$ to $30 \mathrm{~min}$ with a 5 -min active recovery in between. On Friday's, aerobic interval training were performed at a $\mathrm{HR}$ equivalent to $90 \%$ of $\mathrm{VO}_{2}$ peak. The interval prescription (min:min) was a single pyramid of 1:1, 2:2, 3:2, 3:2, 2:2, and 1:2 for a total of 6 intervals and progressed to (min:min) 2 pyramids of $1: 1,2: 2,3: 2,2: 2$, and $1: 1$, with 5 min of light cycling in between pyramids, for a total of 10 intervals. The cyclists trained on their own racing bicycles using stationary training devices. All cycling sessions were supervised and HR was monitored and recorded in training log books and on a poster board in the training room. Any missed session was required to be made up before final testing. Maintenance strength training was allowed once per week and was performed on an off day from the cycle training (Wednesday or Saturday). These sessions were unsupervised and consisted of a general upper and lower body exercise program of the participants own choosing. These sessions were also recorded.

\section{Statistical Analyses}

A one-way analysis of variance (ANOVA) was used to compare all nutrition variables between the WS and PLA groups prior to training. A two-way analysis of variance (group by training) with one repeated measure factor (training) was used to compare body mass, endurance performance, aerobic fitness and heart rate responses. A three-way ANOVA (group by exercise responses by training effect) with two repeated measure factors (exercise and training responses) was used to compare all blood variables at rest and after 5 and $60 \mathrm{~min}$ of recovery, before and after training. A Newman-Keuls multiple comparison procedure was used to further examine any significant F-ratios. Significance was set at $P<0.05$.

\section{RESULTS}

Total caloric intake was $3,320 \pm 1,088 \mathrm{kcal} \cdot \mathrm{d}^{-1}$ for the WS group and $3,168 \pm 935 \mathrm{kcal} \cdot \mathrm{d}^{-1}$ for the PLA group $(\bar{X} \pm \mathrm{SD})$ examined prior to training. The proportion of protein, carbohydrate and fat was $14 \pm 2,58 \pm 7$, and $27 \pm 6 \%$ for the WS group and 15 $\pm 2,56 \pm 4$ and $28 \pm 5 \%$ for the PLA group, respectively. Prior to protein supplementation, the mean $( \pm S D)$ amount of dietary intake of protein was $1.52 \pm 0.45$ and $1.46 \pm 0.44 \mathrm{~g} \cdot \mathrm{kg}^{-1} \cdot \mathrm{d}^{-1}$ for the WS and PLA groups, respectively. There were no significant differences between groups for any of these variables (data not shown).

There was an increase in $\mathrm{VO}_{2}$ peak, VT1 and VT2 and a decrease in time for the $40 \mathrm{~km}$ TT and body mass after 6 weeks of training (main effect, $P<0.05$ ). There was no change in HR responses during either exercise test and no differences between WS and PLA groups (Table 1).

There was a significant exercise response and training effect interaction for white blood cells, neutrophils and lymphocytes counts but no differences were observed between the WS and PLA groups. There was an increase in total white blood cells (Figure 1) and neutrophil counts (Figure 2) after 5 and $60 \mathrm{~min}$ of recovery from the $40 \mathrm{~km}$ TT in both groups $(P<0.05)$. Total white blood cells and neutrophils counts were also lower at 5 and $60 \mathrm{~min}$ of recovery after training compared to the same time points before training $(P<0.05)$. Lymphocytes significantly increased after $5 \mathrm{~min}$ of recovery and significantly decreased after $60 \mathrm{~min}$ of recovery compared to rest and $5 \mathrm{~min}$ of recovery (Figure 3). Lymphocytes also were significantly lower after 60 min of recovery with training in both groups compared to before training $(P<0.05)$. There were no significant differences in NKCA lytic units between groups, after exercise or after training (Figure 4).

\section{DISCUSSION}

Protein is an essential component in an athlete's diet. Protein supplementation following resistance training enhances muscle mass accretion and strength gains (32), however, the effects of protein supplementation to enhance endurance training adaptations are less known. This study sought to examine whether a whey protein supplement in addition to a typical diet would influence endurance training adaptations (i.e., cardiorespiratory fitness, $40 \mathrm{~km}$ time trial performance, and immune system response to exercise). The main findings of the present study were that $1 \mathrm{~g} \cdot \mathrm{kg}$ body mass ${ }^{-1} \cdot \mathrm{d}^{-1}$ of a whey protein isolate in addition to their regular diet $\left(\sim 1.5 \mathrm{~g} \cdot \mathrm{kg}^{-1} \cdot \mathrm{d}^{-1}\right)$ in cyclists undergoing 6 weeks of progressive training did not differentially influence $\mathrm{VO}_{2} \max$, ventilatory threshold, performance, or the 
TABLE 1 | Body mass, aerobic fitness (VT1, VT2, and $\mathrm{VO}_{2}$ peak), and performance (40 km TT) for participants supplementing their diet with whey (WS) or placebo (PLA).

\begin{tabular}{|c|c|c|c|c|}
\hline Variable & \multicolumn{2}{|c|}{ ws } & \multicolumn{2}{|c|}{ PLA } \\
\hline VT1 $\left(L \cdot \mathrm{min}^{-1}\right)$ & $2.54 \pm 0.30$ & $2.80 \pm 0.36^{\star}$ & $2.55 \pm 0.50$ & $2.79 \pm 0.40^{*}$ \\
\hline VT2 $\left(\mathrm{L} \cdot \mathrm{min}^{-1}\right)$ & $3.29 \pm 0.31$ & $3.49 \pm 0.35^{*}$ & $3.33 \pm 0.68$ & $3.54 \pm 0.59^{*}$ \\
\hline $\mathrm{VO}_{2}$ peak $\left(\mathrm{mL} \cdot \mathrm{min}^{-1} \cdot \mathrm{kg}^{-1}\right)$ & $52.3 \pm 6.1$ & $56.1 \pm 5.4^{\star}$ & $50.0 \pm 7.1$ & $54.9 \pm 5.1^{\star}$ \\
\hline $40 \mathrm{~km} \mathrm{TT}$ (min) & $71.47 \pm 12.17$ & $64.38 \pm 8.09^{*}$ & $72.33 \pm 12.79$ & $61.13 \pm 8.97^{\star}$ \\
\hline $40 \mathrm{~km} \pi \mathrm{HR}\left(\mathrm{b} \cdot \mathrm{min}^{-1}\right)$ & $175 \pm 11$ & $174 \pm 12$ & $179 \pm 7$ & $177 \pm 5$ \\
\hline
\end{tabular}

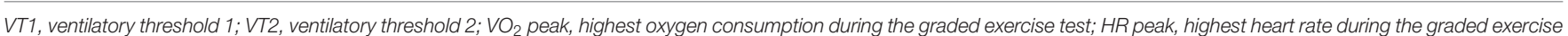
test; TT, time trial; TTHR, mean heart rate during the cycling time trial." significantly different from before training, $P<0.05$. Values are means $\pm S D$.

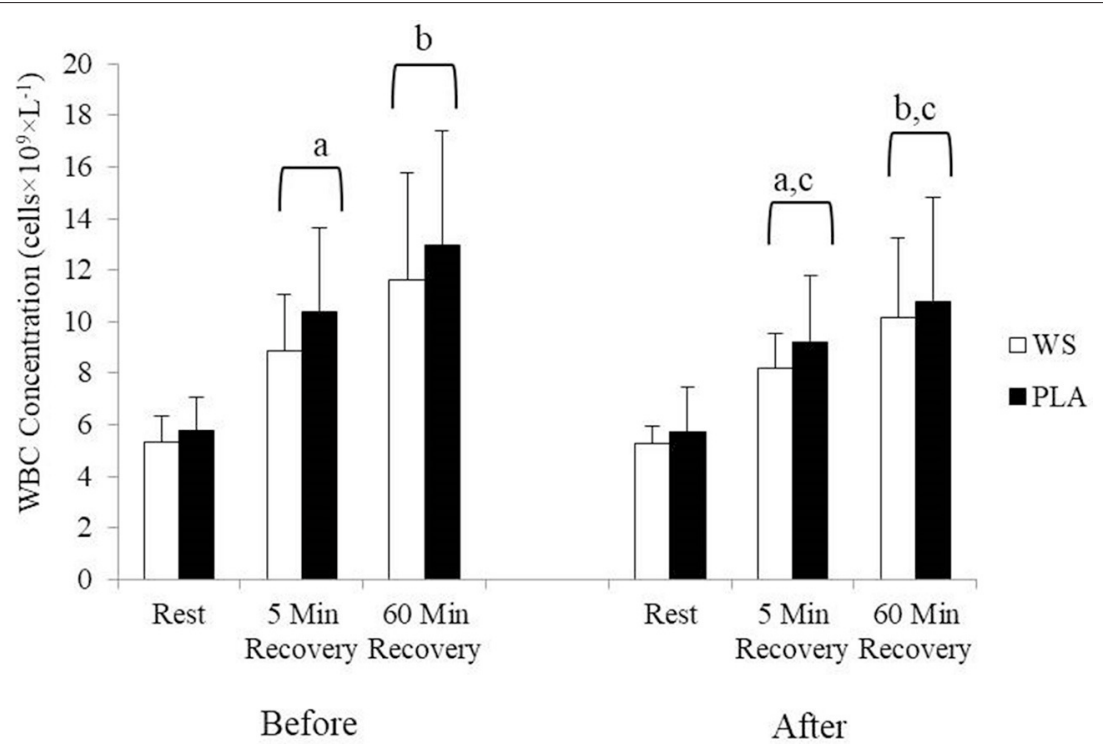

FIGURE 1 | White blood cell concentration at rest, 5 and 60 min after exercise before and after training for the whey supplement (WS) and placebo (PLA) groups. Values are means $\pm \mathrm{SD}$. a, significantly different from rest, $P<0.05$; b, significantly different from rest and 5 min after exercise, $P<0.05$; c, significantly lower at 5 and 60 min of recovery after training, $P<0.05$.

immune response to intense exercise compared to an iso-caloric carbohydrate condition.

Many athletes report that they consume protein supplements to enhance recovery from exercise and training, for health and performance, and to strengthen the immune system response to exercise $(16,33)$. Specifically, higher dietary protein during endurance training is thought to be due to increased cellular protein synthesis requirements (9), greater metabolic demand (34), and optimal functioning of the endocrine and immune systems (17, 23, 33). Recently, Kato et al. (5), examined the protein requirements of endurance training athletes using the indicator of amino acid methodology. They found that endurance trained athletes require $1.8 \mathrm{~g} \cdot \mathrm{kg}^{-1} \cdot \mathrm{d}^{-1}$ to support training adaptations. Williamson et al. (9) used a doubleblind randomized crossover design in 10 male endurance runners, where they examined whole body protein synthesis while consuming a low $\left(0.94 \mathrm{~g} \cdot \mathrm{kg}^{-1} \cdot \mathrm{d}^{-1}\right)$, moderate (1.2 $\left.\mathrm{g} \cdot \mathrm{kg}^{-1} \cdot \mathrm{d}^{-1}\right)$, or high $\left(1.83 \mathrm{~g} \cdot \mathrm{kg}^{-1} \cdot \mathrm{d}^{-1}\right)$ protein diet for 4 days. Net protein balance showed a dose-response with only the high protein diet being positive. They also showed a trend $(P=0.06)$ for the high protein diet to enhance $5 \mathrm{~km}$ time trial performance compared to the low protein diet. These short term effects did not translate to longer term benefits in the latter study. Roberson et al. (11) found that $5 \mathrm{~km}$ time trial performance after 10 weeks of training increased $2.7 \%$ when the participants were supplemented with protein compared to a $6.4 \%$ increase in a non-caloric placebo condition. Our results support these findings following 6 weeks of endurance training in cycling time trial performance. Despite a lack of statistical difference, it is interesting to note that Roberson et al. (11) and our results found that protein supplementation may have attenuated improvements in time trial performance 


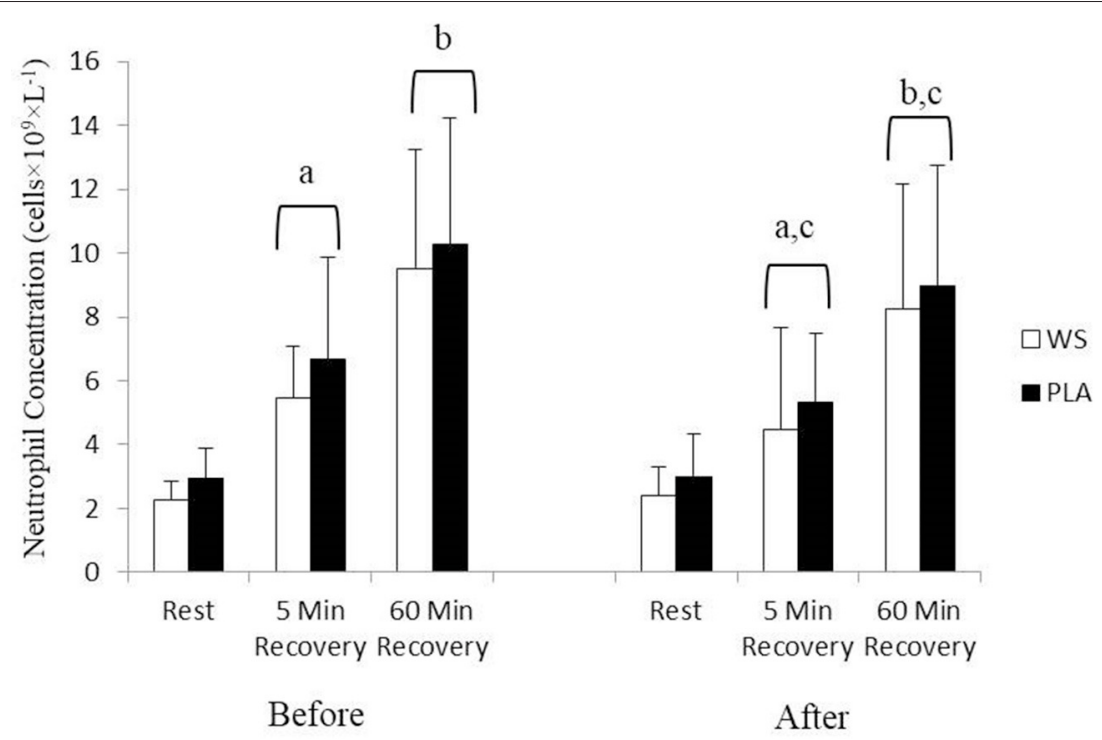

FIGURE 2 | Neutrophil concentration at rest, 5 and 60 min after exercise before and after training for the whey supplement (WS) and placebo (PLA) groups. Values are means $\pm \mathrm{SD}$. a, significantly different from rest, $P<0.05$; b, significantly different from rest and 5 min after exercise, $P<0.05 ; \mathrm{c}$, significantly lower at 5 and 60 min of recovery after training, $P<0.05$.

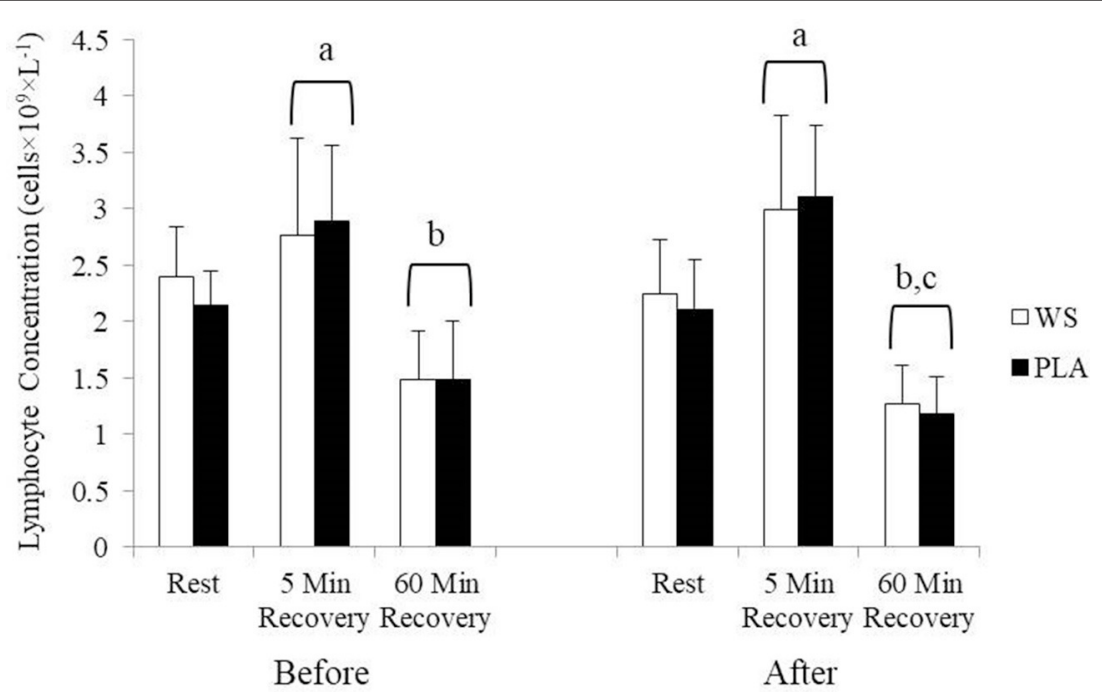

FIGURE 3 | Lymphocyte concentration at rest, 5 and 60 min after exercise before and after training for the whey supplement (WS) and placebo (PLA) groups. Values are means $\pm \mathrm{SD}$. a, significantly different from rest, $P<0.05$; b, significantly different from rest and 5 min after exercise, $P<0.05$; c, significantly lower at 60 min of recovery after training, $P<0.05$.

compared to either a non-caloric or a carbohydrate iso-caloric placebo. But caution is advised in this interpretation and future research will be required to determine whether protein supplementation may in fact be detrimental to some types of endurance performance.

Mitochondrial content and function is important for health and performance. Previous research has shown that protein supplementation following endurance exercise was able to enhance whole body oxygen uptake (13). However, Breen et al. (35) found that following $90 \mathrm{~min}$ of cycling, post exercise ingestion of carbohydrates $(25 \mathrm{~g})$ with whey protein $(10 \mathrm{~g}) \mathrm{did}$ not further augment mitochondrial protein synthesis compared to carbohydrate alone. Roberson et al. (11) also determined that 10 weeks of whey protein supplementation did not alter lower-limb mitochondrial capacity, which further supports the contention that whey protein supplementation likely does not affect training induced mitochondrial biogenesis. The present findings support these observations in that meaningful training adaptations in mitochondrial capacity were not enhanced with protein supplementation. 


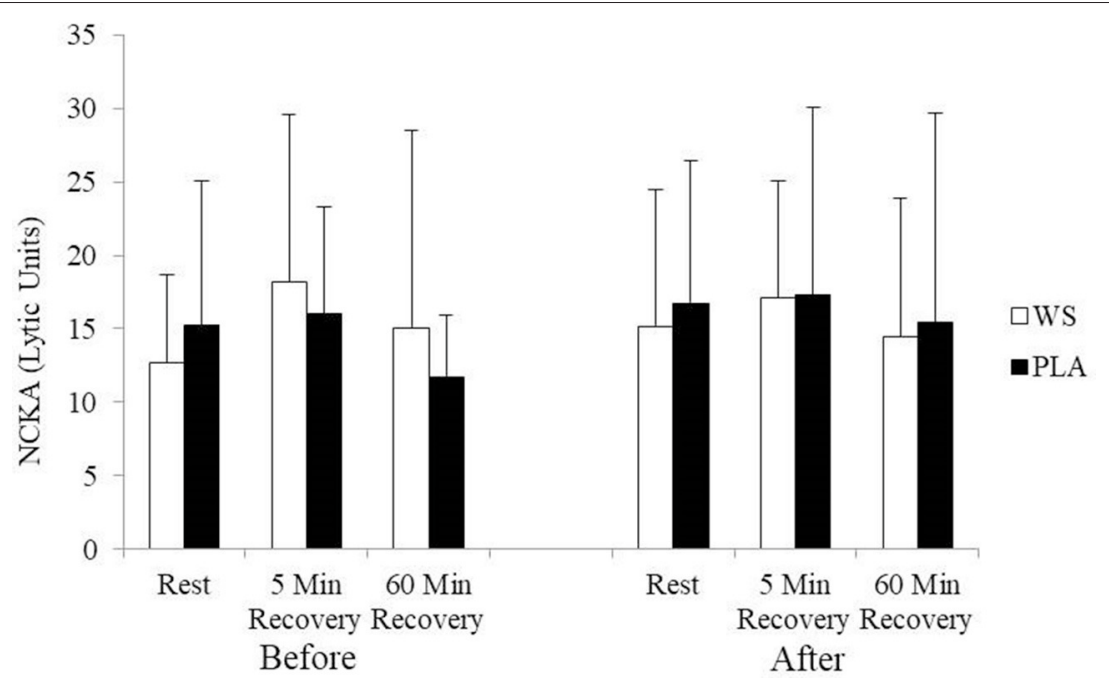

FIGURE 4 | Natural killer cell activity (NKCA) at rest, 5 and 60 min after exercise before and after training for the whey supplement (WS) and placebo (PLA) groups. Lytic units, effector cells $\times 10^{3}$ to lyse $30 \%$ of target cells. Values are means \pm SD.

With regards to immune responses, our research supports previous findings (11). Mechanistically, several amino acids have been implicated in immune function $(19,24)$. Lymphocyte proliferation, cytokine secretion, and cytotoxicity are dependent upon amino acid availability $(23,24)$. Branched chain amino acids (leucine, isoleucine, and valine) found in whey protein can be used for producing nitrogen for glutamine synthesis (19). Glutamine has been implicated in reduced URTI and a decrease in plasma glutamine has been associated with immuno-depression and increased incidence of minor illness (19). Furthermore, amino acids, in particular leucine, is an important signal for mammalian target of rapamycin (mTOR) which induces a cascade of events that govern lymphocyte function (36). However, despite these potential mechanisms, Roberson et al. (11) found no interaction or group effect for white blood cells, neutrophils, monocytes, or hemoglobin following 10 weeks of endurance training with protein supplementation. The acute temporal immune responses (white blood cells, neutrophils, lymphocytes, and NKCA) to the time trial support previous literature $(29,37-39)$. It is important to note that following training (time effect), there was an attenuation in the rise of white blood cells and neutrophils after 5 and $60 \mathrm{~min}$ of recovery after the time trial compared to before training responses. Similarly, lymphocytes were significantly lower after $60 \mathrm{~min}$ of recovery with training in both groups. These latter findings may support an immunosuppression after training or it is possible that there was a reduced inflammatory response and/or potential changes in various hormonal responses may have occurred following endurance training $(40,41)$. Despite evidence that endurance training can acutely alter the immune system (42), the clinical significance of these alterations warrant further investigations (42).

A potential limitation of the current study, was that the participants were consuming a moderately high protein diet $\left(\sim 1.5 \mathrm{~g} \cdot \mathrm{kg}^{-1} \cdot \mathrm{d}^{-1}\right)$ at the start of the study. Williamson et al. (9) compared a high protein intake $\left(1.8 \mathrm{~g} \cdot \mathrm{kg}^{-1} \cdot \mathrm{d}^{-1}\right)$ compared to a moderate protein intake $\left(1.2 \mathrm{~g} \cdot \mathrm{kg}^{-1} \cdot \mathrm{d}^{-1}\right)$ and a low protein intake $\left(0.94 \mathrm{~g} \cdot \mathrm{kg}^{-1} \cdot \mathrm{d}^{-1}\right)$ on $5 \mathrm{~km}$ time trial performance. They reported a trend toward an interaction $(P$ $=0.06)$ with the high protein intake having a moderate effect size (0.57) over the low protein intake and a small effect size over the moderate protein intake (0.26). We compared participants consuming $\sim 1.5 \mathrm{~g} \cdot \mathrm{kg}^{-1} \cdot \mathrm{d}^{-1}$ to $2.5 \mathrm{~g} \cdot \mathrm{kg}^{-1} \cdot \mathrm{d}^{-1}$, and it would be hypothesized based on Williamson et al. (9) that the effect size would have been small. However, the purpose of our study was to examine whether endurance trained participants could benefit from an increase in protein via protein supplementation without modifying their typical diet. This design improves the external validity of the present study.

Another limitation of the present study is the lack of functional immune markers (for example, phagocyte functions (e.g., neutrophil phagocytosis, oxidative burst, degranulation), antigen presenting cell functions, and $\mathrm{T}$ cell functions; 43). Despite our findings on leukocyte counts and NKCA, future research is warranted to examine the impact of protein supplementation and endurance exercise on other immune markers which may be more clinically relevant to URTI risk $(23,43)$. In addition, the training may not have been intense enough to cause an increased risk of URTI, thus potentially limiting the immuno-modulatory effects of protein supplementation $(19,23)$.

\section{CONCLUSION}

Despite short term or acute studies demonstrating an enhanced effect of protein supplementation on endurance training and performance, the present study found no effect of 1.0 $\mathrm{g} \cdot \mathrm{kg}^{-1} \cdot \mathrm{d}^{-1}$ of whey protein isolate in addition to a typical diet $\left(\sim 1.5 \mathrm{~g} \cdot \mathrm{kg}^{-1} \cdot \mathrm{d}^{-1}\right)$ on cardio-respiratory fitness, $40 \mathrm{~km}$ 
cycling performance, or certain immune responses to exercise. Endurance training regardless of supplementation altered some exercise immune responses. Future research examining dietary protein intake and endurance training over longer periods $(>3$ months) of time may be required.

\section{ETHICS STATEMENT}

This study was carried out in accordance with the recommendations of "The Human Research Ethics Boards guidelines, health/biomedical committee" with written informed consent from all subjects. All subjects gave written informed consent in accordance with the Declaration of Helsinki. The protocol was approved by the University of Alberta, Research Ethics Board.

\section{REFERENCES}

1. Thomas DT, Erdman KA, Burke LM. American college of sports medicine joint position statement. nutrition and athletic performance. Med Sci Sports Exerc. (2016) 48:543-68. doi: 10.1249/MSS.0000000000000852

2. Jäger R, Kerksick CM, Campbell BI, Cribb PJ, Wells SD, Skwiat TM, et al. International society of sports nutrition position stand: protein and exercise. $J$ Int Soc Sports Nutr. (2017) 14:20. doi: 10.1186/s12970-017-0177-8

3. The American Dietetic Association, Dietitians of Canada, American College of Sports Medicine, Rodriguez NR, Di Marco NM, Langley S. American college of sports medicine position stand. nutrition and athletic performance. Med Sci Sports Exerc. (2009) 41:709-31. doi: 10.1249/MSS.0b013e31890eb86

4. Institute of Medicine. Dietary Reference Intakes for Energy, Carbohydrate, Fiber, Fat, Fatty Acids, Cholesterol, Protein, and Amino Acids. Washington, DC: National Academic Press (2004).

5. Kato H, Suzuki K, Bannai M, Moore DR. Protein requirements are elevated in endurance athletes after exercise as determined by the indicator amino acid oxidation method. PLOS ONE. (2016) 11:e0157406. doi: 10.1371/journal.pone.0157406

6. Saunders MJ, Kane MD, Todd MK. Effects of a carbohydrate-protein beverage on cycling endurance and muscle damage. Med Sci Sports Exerc. (2004) 36:1233-8. doi: 10.1249/01.MSS.0000132377.66177.9F

7. Saunders MJ. Coingestion of carbohydrate-protein during endurance exercise: influence on performance and recovery. Int J Sport Nutr Exerc Metab. (2007) 17 (Suppl. S87-103). doi: 10.1123/ijsnem.17.s1.s87

8. Ivy JL, Res PT, Sprague RC, Widzer MO. Effect of a carbohydrate-protein supplement on endurance performance during exercise of varying intensity. Int J Sport Nutr Exerc Metab. (2003) 13:382-95. doi: 10.1123/ijsnem.13.3.382

9. Williamson E, Kato H, Volterman KA, Suzuki K, Moore DR. The effect of dietary protein on protein metabolism and performance in endurance-trained males. Med Sci Sports Exerc. (2018) 51:352-60. doi: 10.1249/MSS.0000000000001791

10. D'Lugos AC, Luden ND, Faller JM, Akers JD, McKenzie AI, Saunders MJ. Supplemental protein during heavy cycling training and recovery impacts skeletal muscle and heart rate responses but not performance. Nutrients. (2016) 8:E550. doi: 10.3390/nu8090550

11. Roberson PA, Romero MA, Mumford PW, Osburn SC, Haun CT, Vann CG, et al. Protein supplementation throughout 10 weeks of progressive run training is not beneficial for time trial improvement. Front Nutr. (2018) 5:97. doi: 10.3389/fnut.2018.00097

12. Ferguson-Stegall L, McCleave EL, Ding Z, Doerner LP, Liu Y, Wang B, et al. Aerobic exercise training adapatations are increased by postexercise carbohydrate-protein supplementation. J Nutr Metab. (2011) 2011:623182. doi: 10.1155/2011/623182

13. Robinson MM, Turner SM, Hellerstein MK, Hamilton KL, Miller BF. Longterm synthesis rates of skeletal muscle DNA and protein are higher during aerobic training in older humans than in sedentary young subjects but

\section{AUTHOR CONTRIBUTIONS}

GB contributed to the conception, design, and collection of the data. SF and GB contributed to the analysis, interpretation of the work, as well as drafted, revised, and edited the manuscript.

\section{FUNDING}

This study was funded by the Dairy Farmers of Canada.

\section{ACKNOWLEDGMENTS}

The authors would like to thank Dr. P. Jelen, Dr. C. Field, Dr. C. Sellar, Dr. M. Penkman, A. Torry, and S. Goruk for their assistance with this study.

are not altered by protein supplementation. FASEB J. (2011) 25:3240-9. doi: 10.1096/fj.11-186437

14. Moore DR, Churchward-Venne TA, Witard O, Breen L, Burd NA, Tipton $\mathrm{KD}$, et al. Protein ingestion to stimulate myofibrillar protein synthesis requires greater relative protein intakes in healthy older versus younger men. J Gerontol A Biol Sci Med Sci. (2015) 70:57-62. doi: 10.1093/gerona/glu103

15. Knuiman P, Hopman MTE, Verbruggen C, Mensink M. Protein and the adaptive response with endurance training: wishful thinking or a competitive edge? Front Physiol. (2018) 9:598. doi: 10.3389/fphys.2018. 00598

16. Maughan RJ, Depiesse F, Geyer H, International Association of Athletics Federations. The use of dietary supplements by athletes. J Sports Sci. (2007) 25 (Suppl. 1):S103-13. doi: 10.1080/02640410701607395

17. Cruzat VF, Krause M, Newsholme P. Amino acid supplementation and impact on immune function in the context of exercise. J Int Soc Sports Nutr. (2014) 11:61. doi: 10.1186/s12970-014-0061-8

18. Smithers GW, Ballard FJ, Copeland AD, De Silva KJ, Dionysius DA, Francis GL, et al. New opportunities from the isolation and utilization of whey proteins. J Dairy Sci. (1996) 79:1454-9. doi: 10.3168/jds.S0022-0302(96)76504-9

19. Bermon S, Castell LM, Calder PC, Bishops NC, Blomstrand E, Mooren FC, et al. Consensus statement immunonutrition and exercise. Exerc Immunol Rev. (2017) 23:8-50.

20. Peake JM, Neubauer O, Walsh NP, Simpson RJ. Recovery of the immune system after exercise. J Appl Physiol. (2017) 122:1077-87. doi: 10.1152/japplphysiol.00622.2016

21. Pedersen BK, Ullum $H$. NK cell response to physical activity: possible mechanisms of action. Med Sci Sports Exerc. (1994) 26:140-6. doi: 10.1249/00005768-199402000-00003

22. Moreira A, Delgado L, Moreira P, Haahtela T. Does exercise increase the risk of upper respiratory tract infections? Br Med Bull. (2009) 90:111-31. doi: 10.1093/bmb/ldp010

23. Witard OC, Turner JE, Jackman SR, Kies AK, Jeukendrup AE, Bosch JA, et al. High dietary protein restores overreaching induced impairments in leukocyte trafficking and reduces the incidence of upper respiratory tract infection in elite cyclists. Brain Behav Immun. (2014) 39:211-9. doi: 10.1016/j.bbi.2013.10.002

24. Li P, Yin YL, Li D, Kim SW, Wu G. Amino acids and immune function. $\mathrm{Br} J$ Nutr. (2007) 98:237-52. doi: 10.1017/S000711450769936X

25. Bhambhani Y, Singh M. Ventilatory thresholds during a graded exercise test. Respiration. (1985) 47:120-28. doi: 10.1159/000194758

26. Hansen G, Blanchard C, Rodgers W, Bell G. Efficacy of prescribing endurance training intensity using the ventilatory equivalents for oxygen and carbon dioxide in untrained men and women. Res Sports Med. (2003) 11: 23-32. doi: 10.1080/0308349

27. Jackson J, Snydmiller G, Game A, Gervais P, Bell G. Investigation of positional differences in fitness of male university ice hockey players and the frequency, 
time spent and heart rate of movement patterns during competition. Int J Kin Sports Sci. (2017) 5:6-15. doi: 10.7575/aiac.ijkss.v.5n.3p.6

28. Neary P, Bell GJ, Quinney HA. Reproducibility in simulated $40 \mathrm{~km}$ time trial cycling and its associated metabolic stress. Res Sports Med. (1999) 9:79-88. doi: 10.1080/15438629909512547

29. Sellar C, Syroutuik D, Field C, Bell G. The effect of dietary control and carbohydrate supplementation on the immune and hormonal responses to rowing exercise. Appl Physiol Nutr Metab. (2006) 31: 588-96. doi: $10.1139 / \mathrm{h} 06-036$

30. Forbes SC, McCargar L, Jelen P, Bell GJ. Dose response of whey protein isolate in addition to a typical mixed meal on blood amino acids and hormonal concentrations. Int J Sport Nutr Exerc Metab. (2014) 24:188-95. doi: 10.1123/ijsnem.2013-0136

31. Areta JL, Burke LM, Ross ML, Camera DM, West DW, Broad EM, et al. Timing and distribution of protein ingestion during prolonged recovery from resistance exercise alters myofibrillar protein synthesis. J Physiol. (2013) 519: 2319-31. doi: 10.1113/jphysiol.2012.244897

32. Morton RW, Murphy KT, McKellar SR, Schoenfeld BJ, Henselmans M, Helms E, et al. A systematic review, meta-analysis and meta-regression of the effect of protein supplementation on resistance training-induced gains in muscle mass and strength in healthy adults. Br J Sports Med. (2018) 52:376-84. doi: 10.1136/bjsports-2017-097608

33. Phillips SM. Dietary protein requirements and adaptive advantages in athletes. Br J Sports Med. (2012) 108:S158-67. doi: 10.1017/S00071145120 02516

34. Tarnopolsky M. Protein requirements for endurance athletes. Nutrition. (2004) 20:662-8. doi: 10.1016/j.nut.2004.04.008

35. Breen L, Philp A, Witard OC, Jackman SR, Selby A, Smith K, et al. The influence of carbohydrate-protein co-ingestion following endurance exercise on myofibrillar and mitochondrial protein synthesis. J Physiol. (2011) 589(Pt 16):4011-25. doi: 10.1113/jphysiol.2011.211888

36. Nicklin P, Bergman P, Zhang B, Triantafellow E, Wang H, Nyfeler B, et al. Bidirectional transport of amino acids regulates mTOR and atutophagy. Cell. (2009) 136:521-34. doi: 10.1016/j.cell.2008.11.044
37. Suzuki K, Sato H, Kikuchi T, Abe T, Nakaji S, Sugawara K, et al. Capacity of circulating neutrophils to produce reactive oxygen species after exhaustive exercise. J Appl Physiol. (1996) 81:1213-22. doi: 10.1152/jappl.1996.81. 3.1213

38. Peake JM, Suzuki K, Wilson G, Hordern M, Nosaka K, Mackinnon L, et al. Exercise-induced muscle damage, plasma cytokines, and markers of neutrophil activation. Med Sci Sports Exerc. (2005) 37:737-45. doi: 10.1249/01.MSS.0000161804.05399.3B

39. Sugama K, Suzuki K, Yoshitani K, Shiraishi K, Kometani T. IL-17, neutrophil activation and muscle damage following endurance exercise. Exerc Immunol Rev. (2012) 18:116-27.

40. Suzuki K. Exhaustive exercise-induced neutrophil-associated tissue damage and possibility of its prevention. J Nanomed Biother Discov. (2017) 7:2. doi: 10.4172/2155-983X.1000156

41. Jeurissen A, Bossuyt X, Ceuppens JL, Hespel P. The effect of physical exercise on the immune system. Ned Tijdschr Geneeskd. (2003) 147:1347-51.

42. Walsh NP, Gleeson M, Shephard RJ, Gleeson M, Woods JA, Bishop NC, et al. Position statement. part one: immune function and exercise. Exerc Immunol Rev. (2011) 17:6-63.

43. Albers R, Bourdet-Sicard R, Braun D, Calder PC, Herz U, Lambert C, et al. Monitoring immune modulation by nutrition in the general population: identifying and substantiating effects on human health. Br J Nutr. (2013) 110 (Suppl. 2):S1-30. doi: 10.1017/S0007114513001505

Conflict of Interest Statement: The authors declare that the research was conducted in the absence of any commercial or financial relationships that could be construed as a potential conflict of interest.

Copyright $\odot 2019$ Forbes and Bell. This is an open-access article distributed under the terms of the Creative Commons Attribution License (CC BY). The use, distribution or reproduction in other forums is permitted, provided the original author(s) and the copyright owner(s) are credited and that the original publication in this journal is cited, in accordance with accepted academic practice. No use, distribution or reproduction is permitted which does not comply with these terms. 